Provided for non-commercial research and education use. Not for reproduction, distribution or commercial use.

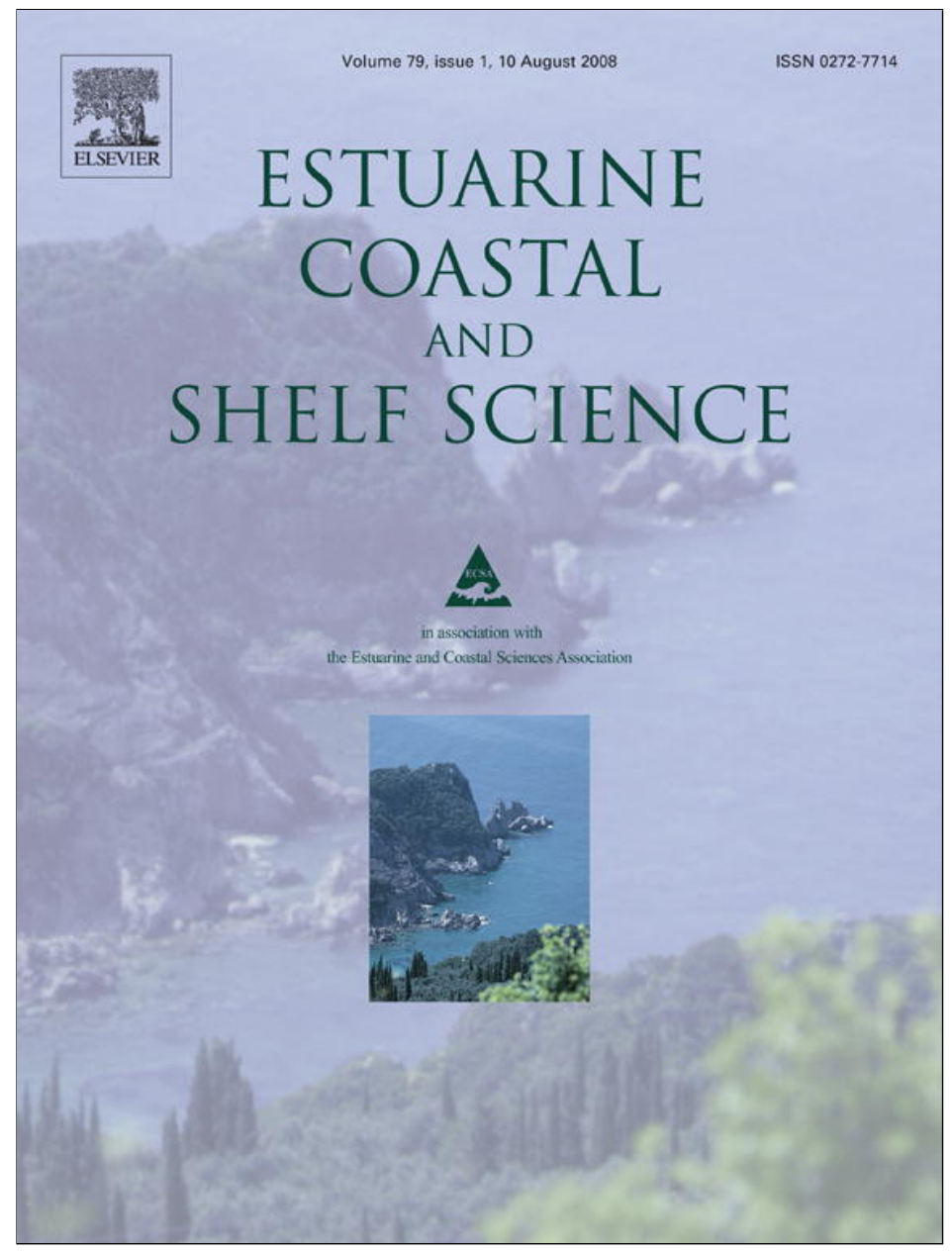

This article appeared in a journal published by Elsevier. The attached copy is furnished to the author for internal non-commercial research and education use, including for instruction at the authors institution and sharing with colleagues.

Other uses, including reproduction and distribution, or selling or licensing copies, or posting to personal, institutional or third party websites are prohibited.

In most cases authors are permitted to post their version of the article (e.g. in Word or Tex form) to their personal website or institutional repository. Authors requiring further information regarding Elsevier's archiving and manuscript policies are encouraged to visit:

http://www.elsevier.com/copyright 


\title{
Long or short? Investigating the effect of beach length and other environmental parameters on macrofaunal assemblages of Maltese pocket beaches
}

\author{
A. Deidun*, P.J. Schembri \\ Department of Biology, University of Malta, Msida, MSD 2080, Malta
}

\section{A R T I C L E I N F O}

\section{Article history:}

Received 1 September 2007

Accepted 3 March 2008

Available online 10 March 2008

\section{Keywords:}

macrofaunal assemblages

sandy beaches

psammophiles

beach length

beach width

\begin{abstract}
A B S T R A C T
Despite numerous published studies that have evaluated the influence of different physical parameters, including beach slope, sediment organic content and grain size, on beach macrofaunal assemblages, very few studies have investigated the influence of beach length on biotic attributes of the same assemblages. Four beaches on the Maltese Islands were sampled using pitfall traps at night for eight consecutive seasons during 2001-2003. Macrofaunal collections were dominated by arthropods, mostly isopods (especially Tylos europaeus) and tenebrionid beetles (especially Phaleria spp.). The environmental variables of beach slope, exposure to wave action, sediment organic content, mean particle diameter, log beach length, beach width and the beach deposit index (BDI) were regressed against a number of biotic parameters, including log individual abundance, total species, Shannon-Wiener $\left(H^{\prime}\right)$ diversity index value and the psammophilic fraction of the total species collected, whilst BIO-ENV and NMDS were used to identify the physical parameter which could best explain observed biotic patterns. RELATE was used to assess the long-term persistence of macrofaunal assemblages on beaches of different lengths. Results from this study suggest that, whilst the influence of beach length and beach width on individual abundance and total species number is unimportant, these 'beach-area' parameters may affect the taxonomic composition of a beach assemblage, mainly in terms of the psammophilic fraction of assemblages, as well as the permanence of macrofaunal assemblages on a beach. Shorter and narrower beaches were found to be more prone to sporadic and random events of colonisation by euryoecious species. In the absence of human disturbance and mass mortality events, beaches of limited dimensions can still maintain stable macrofaunal assemblages. Individual abundance and total species number could not be related to a single or small suite of physical parameters. The study further highlights the need to include biological interactions, the degree of human disturbance and other variables such as environmental heterogeneity and the connectivity of the individual beaches when assessing inter-beach differences in macrofaunal assemblages.
\end{abstract}

(ㄷ) 2008 Elsevier Ltd. All rights reserved.

\section{Introduction}

Total species number and individual abundances of beach macrofauna have been shown to decrease with increasing beach slope and grain size, and with decreasing beach width (e.g. Degraer et al., 2003). The effects of beach length (i.e. distance between headlands) on these biotic parameters have, however, hardly been addressed, with the exception of the studies by Rodil et al. (2006) and Brazeiro (1999). The latter postulates that the total number of species may increase with beach length, with short and 'pocket' beaches supporting fewer species than longer ones, although the

\footnotetext{
* Corresponding author.

E-mail address: alpra1@mail.global.net.mt (A. Deidun).
}

relationship between beach length and total species number is not obvious and may be non-linear and scale-dependent. According to McLachlan and Dorvlo (2005), however, the effects of beach length on total species number are not clearly understood.

Rodil et al. (2006) list beach length, along with slope and wave height, as the main environmental variables affecting the total species number, individual abundance and biomass of macrofaunal communities on intermediate-sized beaches. These authors, however, suggest that different macrofaunal species exhibit different responses to increasing beach length. While most species (e.g. the amphipod Bathyporeia pelagica, the bivalve Donax trunculus and the cumacean Cumopsis fagei) found in the lower beach levels showed higher densities on longer beaches, species of the upper beach (e.g. the polychaete Ophelia bicornis and the amphipod Talorchestia brito) showed an opposite trend, whilst the density of other species 
(for example, the amphipod Talitrus saltator) was not influenced by beach length.

For Mediterranean beaches, there have been very few investigations on the influence of any physical parameters, including beach length, on the biotic assemblages (e.g. Covazzi Harriague and Albertelli, 2007). Of these, even fewer studies have considered the influence of physical parameters on non-marine supralittoral macrofauna (e.g. insects) in their analyses. Colombini and Chelazzi (1996) examined the influence of air temperature, relative humidity, pressure, wind speed and direction, sand temperature and moisture, water level and light intensity on the surface activity of the carabid Eurynebria complanata. Carpaneto and Fattorini (2001) looked at the influence of plant cover on tenebrionid communities, while Colombini et al. (2005) studied the influence of $\mathrm{pH}$, sand moisture and organic matter, sediment granulometry and salinity on the distribution of selected beach arthropods, and Fallaci et al. (1997) examined the influence of temperature, air humidity, sand moisture and light intensity on the activity of psammophilic tenebrionids). None of these studies considered the effect of beach length on the beach macrofaunal assemblages.

The sandy beaches of the Maltese Islands fit the definition of pocket beaches as given by the New South Wales (Australia) Coastal Management Manual (Australian Government, 2007), that is, beaches along which no significant lateral, long shore drift occurs because they are contained between two headlands. All Maltese beaches are small (the longest beach, that of Ghadira, is only $1 \mathrm{~km}$ long) and are flanked by headlands on both sides, which diffract waves and reduce long shore sediment movement. Maltese beaches are considered to be 'sediment-tight' systems (Micallef, 2003).

It has been hypothesised that community parameters such as the total number of species and individual abundance will show a positive correlation with beach length. The 'rescue effect' (immigration reduces extinction rate (Brown and Kodrick-Brown, 1977)) has been invoked to explain the higher diversity found within continuous patches of habitat with respect to fragmented habitat patches. By using Maltese beaches as a test, this study aims to investigate whether increasing beach length (defined as the distance between the headlands of a beach) results in higher total species number and individual abundance within psammophilic (i.e. beach-specific) arthropod communities, and whether beaches of limited length can sustain long-term populations of these species.

\section{Materials and methods}

\subsection{Macrofaunal sampling}

Four Maltese beaches of different length, varying from $80 \mathrm{~m}$ (Xatt l-Ahmar) to $500 \mathrm{~m}$ (Ramla l-Hamra) were sampled (Fig. 1). Table 1 gives selected characteristics of the beaches sampled.

Due to beach length considerations, one transect was used on the beach at Xatt l-Ahmar, two transects were used on the beach of White Tower Bay and three transects were used on the beaches of Ramla l-Hamra and Golden Bay. Transects were divided into a wet and dry zone, using the strandline as the boundary between the two zones. This was possible since the maximum tidal range on the Maltese Islands is only $20 \mathrm{~cm}$. Samples were collected in eight consecutive seasons, from autumn 2001 to summer 2003. Constellations of pitfall traps, each consisting of five plastic cups $(7.5 \mathrm{~cm}$ diameter and a height of $10 \mathrm{~cm}$ ) arranged one at the centre and the other four in a cross pattern separated from the central cup by a distance of $1 \mathrm{~m}$, were used to collect nocturnal, surface active fauna. Each cup was inserted into the sand such that the rim was flush with the sediment surface. The peripheral traps were connected to the central one by thin strips of 'Plexiglas' resting on the sand, which served as walk-ways. Traps were left overnight and

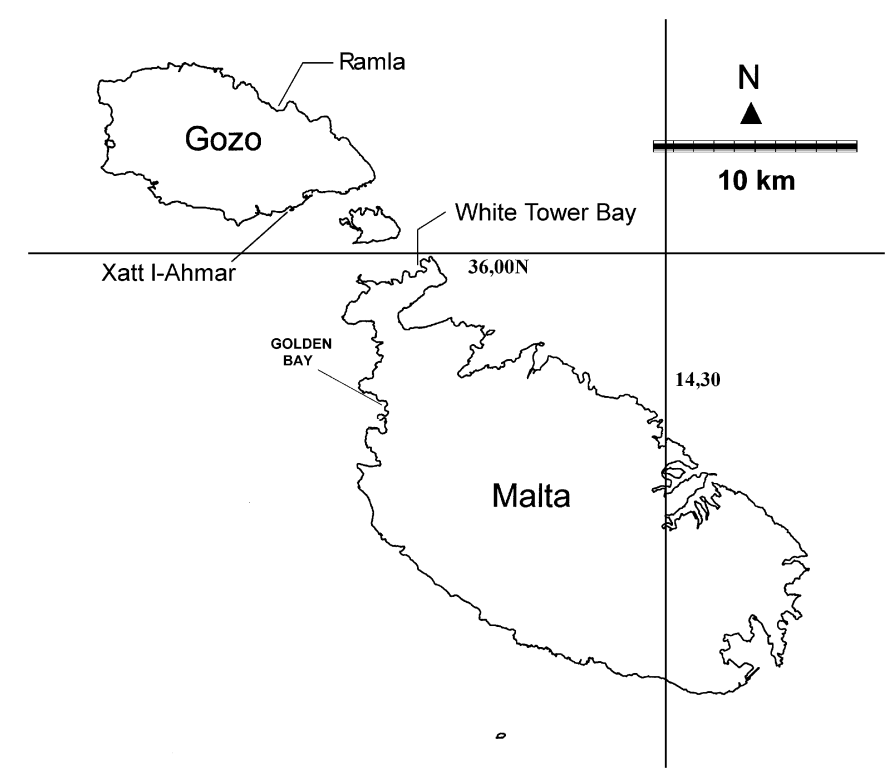

Fig. 1. Geographical location of the Maltese beaches studied.

emptied in the morning. A pitfall trap constellation was placed in the wet and dry zone of each transect. The number of transects and pitfall trap constellations per beach resulted in little variability in sampling effort, which ranged from 1 constellation $2000 \mathrm{~m}^{-2}$ of beach area to 1 constellation $3000 \mathrm{~m}^{-2}$ of beach area. Macrofauna collected were identified and counted, and collections were standardized to individuals per trap per hour.

\subsection{Monitoring of environmental parameters}

Beach environmental parameters monitored were the mean grain size of the sediment, the percentage organic content of the sediment, beach slope and exposure to wave action, whilst the length and width of each of the beaches sampled were also measured. Exposure to wave action was determined using the method described by Thomas (1986). The parameter 'beach length' was log transformed to reduce the large differences in values obtained for the different beaches (range $0.08-0.50 \mathrm{~km}$ ). A difficulty encountered in the present study when assessing the effect of beach width on macrofaunal communities was the definition of beach width itself, which is not always clear in the literature. For the purpose of the present study, beach width was taken to be the maximum extent of the 'bare-sand, unvegetated width' of the beach (i.e. excluding even dunal remnants). Under such a definition, Ramla l-Hamra exhibited the largest beach width (maximum $100 \mathrm{~m}$ ), whilst Xatt L-Ahmar exhibited the smallest beach width (maximum $18 \mathrm{~m}$ ). Beach width maxima were used in the statistical analyses.

\subsection{Statistical analyses}

For each beach, the total individual abundance $(N)$ was calculated; values were then log transformed to down weight the importance of the very abundant species in order to allow rare species to play some role in determining similarity between samples (Clarke and Warwick, 1994). Total species $(S)$ as well as values for the Shannon-Wiener $\left(H^{\prime}\right)$ diversity index $\log _{2}$ were calculated for each beach.

The number of species recorded exclusively on just one beach was expressed as a percentage of the total number of species recorded from the same beach, whilst the psammophilic fraction of the total number of species was also estimated (Table 1). 
Table 1

Values for environmental parameters and two selected biotic parameters for the beaches sampled. Mean parameter values (along with the corresponding standard deviation (SD) values) are reported

\begin{tabular}{|c|c|c|c|c|c|c|c|c|c|c|}
\hline Beach & $\begin{array}{l}\text { Beach } \\
\text { length } \\
(\mathrm{km})\end{array}$ & $\begin{array}{l}\text { Beach } \\
\text { width } \\
\text { (m) }\end{array}$ & $\begin{array}{l}\text { BDI } \\
\text { index } \\
\text { value }\end{array}$ & $\begin{array}{l}\text { Mean percentage } \\
\text { sediment organic } \\
\text { content (\% (SD)) }\end{array}$ & $\begin{array}{l}\text { Exposure to } \\
\text { wave action } \\
\text { value }\end{array}$ & $\begin{array}{l}\text { Mean grain } \\
\text { size (phi (SD)) }\end{array}$ & $\begin{array}{l}\text { Mean beach } \\
\text { slope } \\
\text { (degrees (SD)) }\end{array}$ & $\begin{array}{l}\text { Mean } \mathrm{H}^{\prime} \\
\text { values (SD) }\end{array}$ & $\begin{array}{l}\text { Percentage } \\
\text { of single-beach } \\
\text { species }\end{array}$ & $\begin{array}{l}\text { Psammophilic } \\
\text { fraction (based } \\
\text { on species) (\%) }\end{array}$ \\
\hline White Tower Bay & 0.12 & 85 & 4.87 & $0.075(0.019)$ & 6.19 & $2.83(0.90)$ & $1.45(0.88)$ & $0.97(0.54)$ & 32.1 & 17.9 \\
\hline Golden Bay & 0.22 & 75 & 2.00 & $0.075(0.020)$ & 6.80 & $1.66(0.45)$ & $1.54(1.20)$ & $1.13(0.58)$ & 30.8 & 25.5 \\
\hline Ramla l-Hamra & 0.50 & 100 & 2.08 & $0.045(0.010)$ & 8.72 & $2.20(0.35)$ & $2.42(1.10)$ & $0.59(0.36)$ & 41.8 & 29.1 \\
\hline Xatt l-Ahmar & 0.08 & 18 & 2.36 & $1.21(0.37)$ & 2.21 & $1.29(0.22)$ & $1.02(0.44)$ & $0.74(0.24)$ & 55.6 & 16.7 \\
\hline
\end{tabular}

Psammophiles are sand-specific species, which were separated from coastal (i.e. present in different coastal habitats, including on rocky shores) and euryoecious/ubiquitous species on the bases of their habitat preferences in Malta as reported in the literature (e.g. Caruso and Lombardo, 1982; Mifsud and Scupola, 1998; Mifsud, 1999; Nardi and Mifsud, 2003) or following consultation with relevant taxonomists (see Acknowledgements). Species which were collected in less than $1.5 \%$ of all pitfall trap samples (considered arbitrarily as an adequate truncation point to eliminate rare species contributing to data noise), or during one season only, were excluded from the analyses.

A number of studies (e.g. Rodil and Lastra, 2004) highlight the usefulness of composite variables/measures, rather than individual variables, in explaining observed biotic patterns. McLachlan et al. (1993) found that Dean's parameter is a good predictor of the total number of species, abundance and biomass for microtidal beaches from different geographic regions; however, since wave-related data were not recorded in the present study, another beach classification index, BDI, was calculated. BDI is commonly used for microtidal beaches under a wide range of conditions and has been applied by McLachlan and Dorvlo (2005) in identifying global patterns in sandy beach macro-benthic communities. The index is calculated as follows:

$\mathrm{BDI}=\left(\frac{1}{\tan B}\right)\left(\frac{a}{\mathrm{Mz}}\right)$

where $\tan B$ is the beach slope, $a$ is $1.03125(\mathrm{~mm})$ and $\mathrm{Mz}$ is the mean sand particle size $(\mathrm{mm})$. Despite the biotic variables monitored being probably dependent on more than one environmental variable, possible correlations between environmental variables (including BDI) and the various biotic parameters were investigated using simple linear regression, as multiple regression analyses could not be applied on the data set available as only four beaches were included in the study.

All diversity measures were calculated using the Species Diversity and Richness v. 3.03 suite of programs (Henderson and Seaby, 2002), whilst regression analyses were carried out using the QED Statistics Package (Seaby and Henderson, 2007).

The Bray-Curtis coefficient was used to estimate similarity between every possible pair of samples in order to construct similarity matrices, which were then subjected to two-dimensional non-metric multi-dimensional scaling (NMDS) ordination. Log beach length, beach width and percent sediment organic content, exposure to wave action, mean grain size and beach slope were used as scaled overlays on the NMDS plot.

The BIOENV procedure (Clarke and Warwick, 1994) was used to examine the relationship between community parameters and environmental variables (including beach length and beach width), thereby defining suites of variables which 'best explain' the patterns emerging from the NMDS plot. The RELATE procedure (Clarke and Warwick, 1994) was used to calculate a rank correlation coefficient between all the elements of two (dis)similarity matrices. Cyclical model similarity matrices generated using biotic data from the shortest (Xatt l-Ahmar) and the longest (Ramla l-Hamra)
Maltese beaches sampled were compared. This was done in order to assess the long-term persistence of macrofaunal assemblages on beaches of different lengths.

In order to gauge the adequacy of sampling efficiency, the Chao and Lee Type II species estimator was computed to estimate the seasonal values of species richness for the various beaches sampled. This non-parametric estimator appears to be one of the most robust species richness estimators (Henderson and Seaby, 2002) and has been recommended by Walther and Moore (2005) as the most suitable (in terms of reduced bias and high precision) species estimators for beetles and invertebrates.

Multivariate statistical analyses were made using the PRIMER 6 (Clarke and Gorley, 2006) and the SPSS v. 13 (Norussis, 1993) statistical packages.

\section{Results}

\subsection{Biotic and abiotic data}

A total of 16,260 individuals belonging to 141 species and 14,556 individuals belonging to 129 species were collected respectively during the first and second year of sampling. All species collected were arthropods. Fauna collected from all the beaches considered together belonged to 17 broad taxonomic groups, with Coleopterans being the most represented in terms of species and Isopoda being the most represented in terms of individual abundance. The most common species in the samples (in terms of individual abundance) were Tylos europaeus, Phaleria acuminata, Phaleria bimaculata, Talitrus saltator and Orchestia stephenseni.

Table 1 gives the values of selected physical parameters for the beaches sampled, together with the total number of species of the psammophilic fraction of the fauna collected, the total individual abundance for each beach, and the percentage (over the total number of species for the beach) of species restricted to single beaches only.

The highest percentage of single-beach species was recorded from the shortest beach (Xatt l-Ahmar), whilst the highest psammophilic fraction was recorded from the longest beach (Ramla 1-Hamra) and the lowest from the shortest beach.

Values obtained for the Chao non-parametric estimate for species richness $(S)$ coincide very closely with the recorded values of species richness, with the exception of White Tower Bay dry zone values, indicating the 'expected' number of species was indeed recorded for every beach through the trapping technique.

\subsection{Biotic-abiotic relationships}

No conclusive correlations between the biotic variables measured $\left(\log N, S\right.$, and $H^{\prime}$ and the psammophilic fraction) and the environmental variables emerged from the simple linear regression analyses. Just four of the 28 regressions carried out were significant $(p=0.05$; d.f. $=3)$. The relevant plots for the significant bioticabiotic regressions are reproduced in Fig. 2A-D. The psammophilic fraction (of the total number of species) was positively correlated 
A

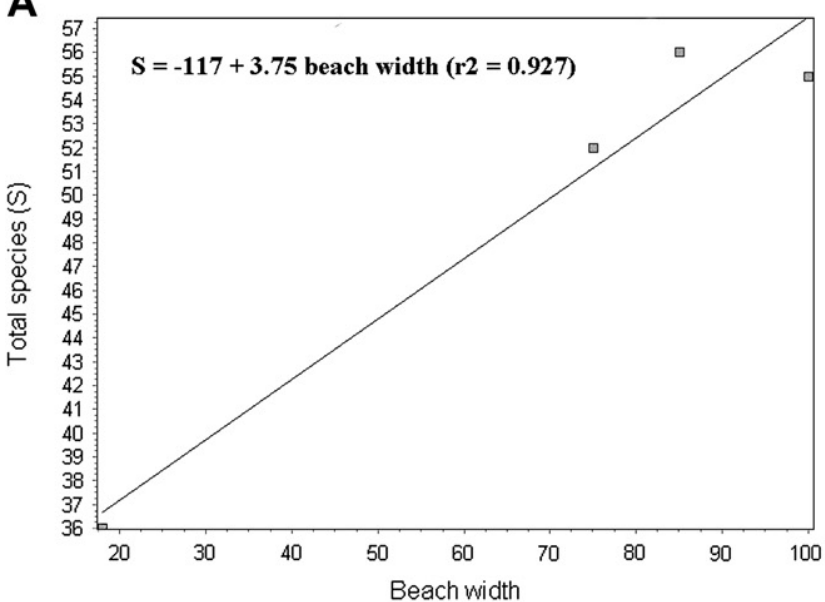

C

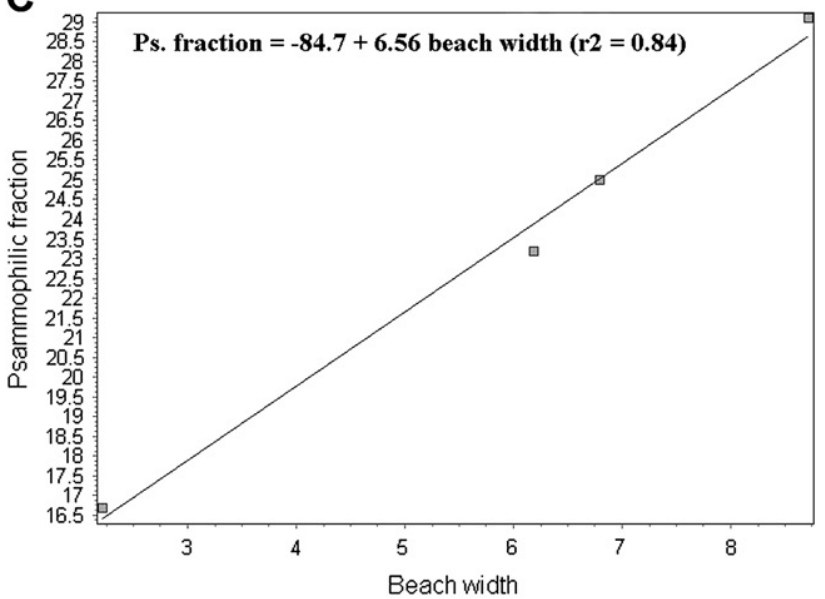

B

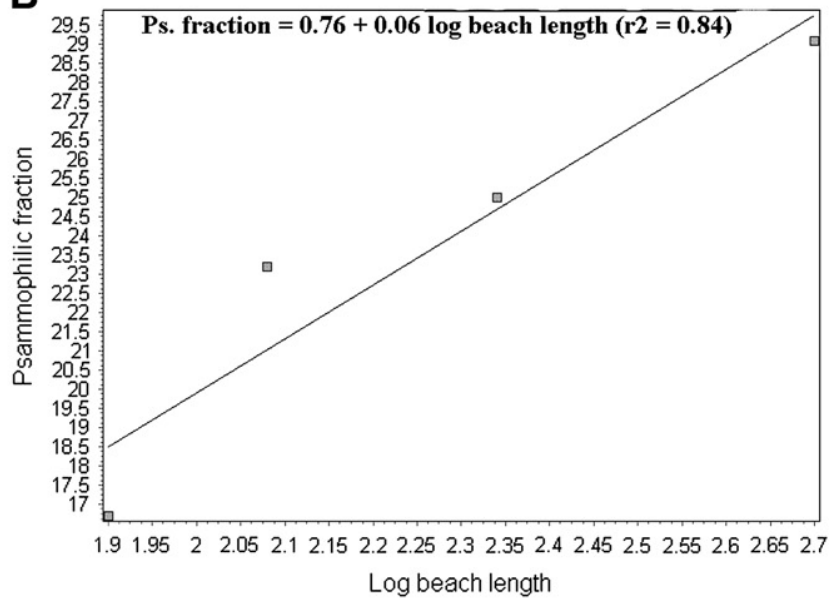

D

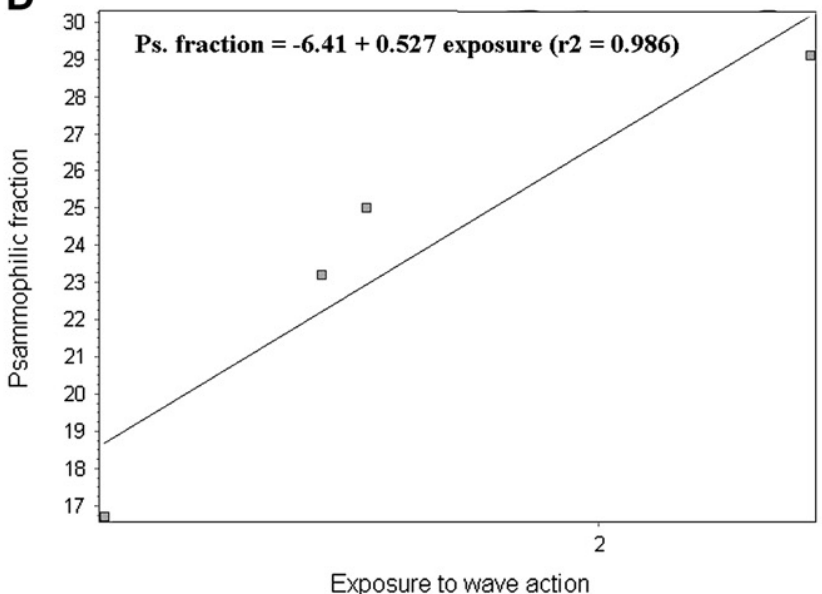

Fig. 2. Scatter plots and regression lines and equations, for significant $(p<0.05)$ regressions between biotic and environmental parameters. The biotic-abiotic regressions are: total species vs beach width (A), the psammophilic fraction vs log beach length (B), the psammophilic fraction vs beach width (C), and the psammophilic fraction vs exposure to wave action (D). Units for beach length are metres, whilst the exposure to wave action is a dimensionless parameter.

with $\log$ beach length and beach width, whilst the total species number $(S)$ was positively correlated with beach width and sediment organic content.

The abiotic-factor combination which gave the highest, albeit still low, correlation factor (rho value 0.370 ) in the BIO-ENV analysis was the beach slope/sediment organic content. The abiotic factor combination involving beach length that had the highest correlation factor was exposure to wave action/beach length/beach width, with a rho value of 0.333 , indicating that beach length is not an important abiotic factor in explaining the observed biotic separation patterns.

Fig. 3 gives the NMDS plot for pitfall trap samples collected during both years of sampling. Of the different physical parameters used as overlays in the NMDS analyses, beach slope and sediment organic content were the most useful in explaining the observed ordination patterns, although they could not fully explain them; the NMDS ordinations overlaid with beach slope and sediment organic content are shown in Fig. 3.

A comparison of cyclical model similarity matrices generated using biotic data from the shortest (Xatt l-Ahmar) and the longest (Ramla 1-Hamra) Maltese beaches sampled, together with an analysis of the single-season collections, was done in order to assess the long-term stability of macrofaunal communities on short beaches. Table 2 gives the results of the RELATE analysis; none of the values obtained were significantly different from the generated cyclic pattern at $p=0.05$.
Table 3 gives the percentage number of times that species were collected from the beaches over the total sampling period. No clear pattern emerges from this table, although the longest Maltese beach (Ramla 1-Hamra) gave the lowest percentage of 'singleseason species' and the shortest Maltese beach (Xatt l-Ahmar) had the highest such percentage. Considering the combined percentages of species collected in four sessions or more (and hence exhibiting inter-annual persistence on a beach), Xatt l-Ahmar had the second highest value (8.7\%), whilst Ramla l-Hamra had the second lowest value (7.2\%).

\section{Discussion}

In the analysis of different Chilean beach assemblages by Brazeiro (1999), simple and multiple linear regression analyses (forward stepwise method) did not show any significant correlation between the total number of species and beach length; however, when the analysis was carried out for the $0.2-2.0 \mathrm{~km}$ range of beach lengths, the total number of species residuals increased with beach length, suggesting that the two are related, although not in an obvious way.

In the present study, beach length did not emerge as an important discriminatory factor when regressed against various biotic factors (with the exception of the psammophilic fraction measure) and was not identified as an important structuring variable in the 
A

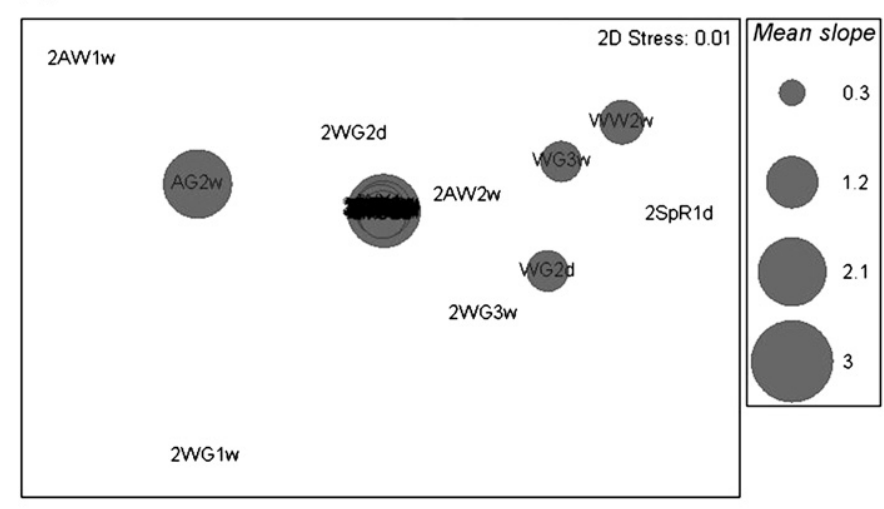

B

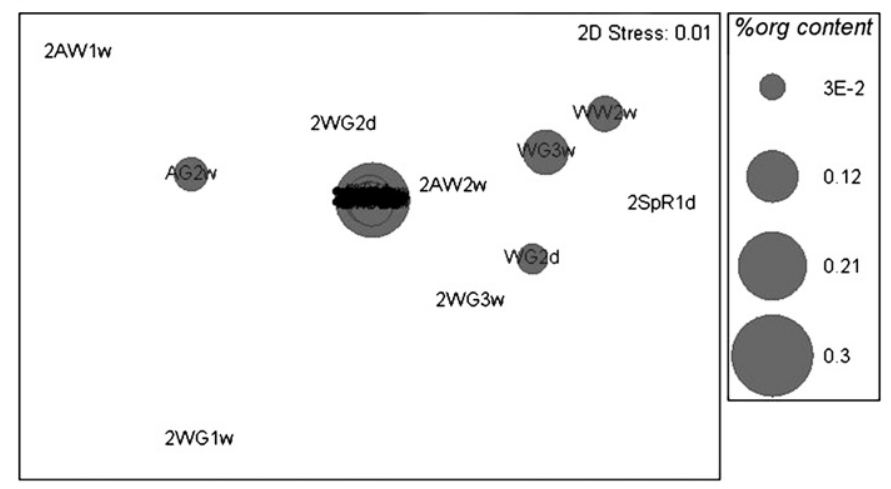

Fig. 3. NMDS plots (using the Bray-Curtis similarity measure) for the pitfall trap data for the four Maltese beaches studied, using the environmental parameters of beach slope (A) and sediment percentage organic content (B) as overlays; these two parameters best explain the biotic separation patterns. Legend: 1st letter, season (A, autumn; W, winter; Sp, spring; Su, summer); 2nd letter, beach (W, White Tower Bay; G, Golden Bay; R, Ramla; X, Xatt L-Ahmar); 3rd letter, beach zone (wet or dry zone).

multivariate analyses. No single environmental variable was useful in explaining the observed biotic separation patterns. On the other hand, the longest and shortest Maltese beaches sampled (Ramla 1-Hamra and Xatt 1-Ahmar respectively) had the largest and smallest psammophilic component of the total number of species recorded from all Maltese beaches, respectively, while the psammophilic fraction was positively correlated $(p<0.05)$ with both log beach length and beach width.

Taxonomic composition is also influenced to an extent by human disturbance (e.g. Scapini et al., 1992; Weslawski et al., 2000;

Table 2

Results of the RELATE analysis. Only wet zone values were used for the two beaches (Ramla l-Hamra and Xatt l-Ahmar). N/A, not available, since no specimens were collected

\begin{tabular}{|c|c|c|c|c|}
\hline \multirow[t]{2}{*}{$\begin{array}{l}\text { Biotic data used } \\
\text { for comparison }\end{array}$} & \multicolumn{2}{|c|}{$\begin{array}{l}\text { Ramla l-Hamra } \\
\text { wet zone }\end{array}$} & \multicolumn{2}{|c|}{$\begin{array}{l}\text { Xatt L-Ahmar } \\
\text { wet zone }\end{array}$} \\
\hline & Rho value & $\begin{array}{l}\text { Significance } \\
\text { level }\end{array}$ & $\begin{array}{l}\text { Rho } \\
\text { value }\end{array}$ & $\begin{array}{l}\text { Significance } \\
\text { level }\end{array}$ \\
\hline Wet zone both years, all fauna & -0.123 & 0.882 & 0.044 & 0.317 \\
\hline Wet zone 1st year, all fauna & 0.000 & 1.000 & -0.207 & 1.000 \\
\hline Wet 2nd year, all fauna & 0.207 & 0.659 & -0.621 & 1.000 \\
\hline Wet both years, Coleoptera & -0.187 & 0.916 & 0.105 & 0.219 \\
\hline 1st year, Coleoptera & 0.414 & 0.327 & -0.414 & 1.000 \\
\hline 2nd year, Coleoptera & 0.414 & 0.689 & -0.207 & 1.000 \\
\hline Wet both years, Amphipoda & $\mathrm{N} / \mathrm{A}$ & & -0.014 & 0.508 \\
\hline 1st year, Amphipoda & 0.207 & 0.326 & 0.207 & 0.666 \\
\hline 2nd year, Amphipoda & $\mathrm{N} / \mathrm{A}$ & & -0.828 & $1.00 \mathrm{p} 0$ \\
\hline
\end{tabular}

Deidun and Schembri, 2004). The two least disturbed beaches (i.e. Xatt 1-Ahmar and Ramla 1-Hamra) showed the highest psammophilic fraction of the total individual abundance recorded. These results seem to indicate that human disturbance mainly influences the macrofaunal species composition of a beach rather than its total individual abundance, with appreciable numbers of non-psammophilic species colonizing sandy beaches in low abundances with increasing human disturbance. In addition, even popular sandy beaches, such as Golden Bay, can have high mean annual $H^{\prime}$ values, suggesting that the postulated decrease in macrofaunal diversity in the summer season is less evident during the rest of the year, indicating a high degree of macrofaunal community recovery.

The inability of the present study to identify a single key physical factor that influences the biotic parameters concords with the observations by Brazeiro (2001) and Rodil and Lastra (2004) that no single physical factor actually accounts for changes in the total number of species, individual abundance and biomass.

The relative lack of biotic-abiotic correspondence might suggest that biological interactions and other site-specific factors, including the extent of dunal vegetation in the back-beach areas or the degree of human disturbance, rather than environmental factors, structure the macrofaunal assemblage on the sandy beaches studied. In fact, some authors, including, Dugan et al. (2004), believe that biological interactions, including competitive ones, not only affect the distributions and zonation of intertidal macro-infauna but potentially also community structure. Studies by Veloso and Cardoso (2001) show that the abundance of the communities was also not related to any physical parameter and these authors suggested that certain biotic factors, such as food source, recruitment, predation and competition, are responsible for the differences in macrofaunal densities between beaches. In addition, Nucci et al. (2001) have demonstrated a relationship between environmental heterogeneity and species richness.

Since the macrofaunal species collected in the present study were predominantly terrestrial, marine connectivity factors, including the degree of long shore current diffraction by headland obstruction, are not expected to play such an important role in the structuring of the beach macrofaunal assemblages.

The discordance between biotic and abiotic data might also be due to the restricted number of sandy beaches sampled in the present study and perhaps also due to insufficient characterisation of the physical environment. Additional physical parameters which were not monitored in this study and which are considered by Colombini et al. (1996) and Fallaci et al. (1996) as regulating the zonation of at least some of the sandy beach macrofauna, include air and sand temperatures, sand water content (especially important for burrowing activity of isopods), the relative humidity of the air and even the sea-land direction of the wind. The inability of the present study to relate beach community parameters (the total number of species and individual abundance) with physical variables is at variance with the observation by Defeo and McLachlan (2005) that biotic population dynamics on reflective beaches are mainly controlled by physical factors. Although no extensive beach classification was conducted in the present study, the beaches sampled can be roughly described as being reflective in nature, due to their generally coarse sand, narrow medio-littoral (analogous, in microtidal conditions, to the intertidal zone) and low sediment organic content.

The general species-deficient nature of the beaches sampled can be attributed to their micro-tidal, reflective conditions, which have been associated with low total species counts (the Habitat Harshness Hypothesis; Defeo et al., 2001). Pocket beaches of reduced length might be considered as ecological islands in their own merit, in view of the lack of long shore currents between them, and due to the paucity of sandy coastlines on the Maltese Islands, which results in the few sandy beaches being separated by long stretches of 
Table 3

Percentage number of species (over total species richness) collected for different sessions of the total sampling sessions for the Maltese beaches. The first column gives species collected in all the eight sampling sessions, whilst the second last column gives species collected during one sampling session

\begin{tabular}{|c|c|c|c|c|c|c|c|c|c|}
\hline \multirow[t]{2}{*}{ Beach } & \multicolumn{9}{|c|}{ Percentage of species collected ( $8 / 8$ collected in all eight sessions; $1 / 8$ collected in only one session of the eight sampling sessions) } \\
\hline & $8 / 8$ & $7 / 8$ & $6 / 8$ & $5 / 8$ & $4 / 8$ & $3 / 8$ & $2 / 8$ & $1 / 8$ & Total \\
\hline Xatt l-Ahmar & 2.9 & 0 & 0 & 5.9 & 2.9 & 8.8 & 11.8 & 67.6 & 100 \\
\hline Ramla l-Hamra & 0 & 3.6 & 0 & 3.6 & 3.6 & 14.5 & 21.8 & 52.7 & 100 \\
\hline Golden Bay & 2.0 & 0 & 2.0 & 2.0 & 2.0 & 8.0 & 24.0 & 60.0 & 100 \\
\hline White Tower Bay & 3.1 & 3.1 & 0 & 6.3 & 0 & 6.3 & 25.0 & 56.3 & 100 \\
\hline
\end{tabular}

non-sandy coastline (Deidun and Schembri, in press); this is presumed to hinder inter-beach biotic recruitment. Such a lack of recruitment to beaches of reduced length is especially significant when considering the effect of stochastic events, including severe storms, and of human disturbance, which might extirpate particular species from a beach. Beaches from where such species have been extirpated may remain without these species for long periods of time due to the reduced inter-beach dispersal as a result of their isolated nature. Jaramillo et al. (1996) are of the opinion that naturally occurring disturbances are far more disruptive events than mechanical disturbance by human activity.

McLachlan and Dorvlo (2005) state that small beaches cannot sustain stable macrofaunal communities; the present study gave conflicting results with respect to this claim. The RELATE analysis indicated that the whole beach macrofaunal assemblage as well as selected macrofaunal taxa did follow a cyclical pattern of variation over the two sampling years, hinting at a possible inter-annual community persistence. This might suggest one of two things: (1) if a critical beach length, below which long-term biotic community stability and permanence are not possible, does exist then this length must be below $80 \mathrm{~m}$ (the length of the beach at Xatt 1-Ahmar), at least for Maltese beaches; or (2) that effective interbeach recruitment is occurring.

A large fraction of the species collected in this study (77 species, $40.3 \%$ ) was collected from single beaches only. This suggests that there is little inter-beach connectivity. This is not surprising given that Maltese shores are predominantly rocky with just $2.4 \%$ of the 210-km long coastline consisting of sand or shingle (Axiak et al., 1999) and that most Maltese beaches are isolated by headlands and by long stretches of rocky coastline.

For all the beaches sampled and irrespective of their length, the majority of species collected were recorded during one sampling season only (percentage of 'single-season' species ranging from 52.7 to $67.6 \%$ ). The percentage of species collected in less than 4 out of the total 8 seasons sampled (hence, not showing inter-annual persistence) ranged from 87.6 to $92.0 \%$ on the same beaches. Besides the instability of macrofaunal communities on small pocket beaches, stochastic events, which contribute to the variability in species composition on a beach, may explain these observations. Post-storm recolonisation of the beaches studied may result from recruitment from back-beach dunal areas, rather than from adjacent beaches-three of the four beaches sampled in the present study were backed by small pockets of degraded dune remnants (the exception was Xatt l-Ahmar which was too narrow for a dune to develop but was backed by vegetated clay slopes). This emphasises the ecological importance of dune remnants as potential refugia for psammophilic species, even when such remnants are degraded, although further studies on the degree of overlap between dunal and beach faunal populations are necessary to assess this.

\section{Conclusion}

In conclusion, the results of this study suggest that 'beach area' considerations, including beach length and width, whilst not immediately important in structuring beach macrofaunal communities, might impinge on the taxonomic composition of such assemblages, with shorter and narrower beaches being more prone to sporadic and random events of colonisation by euryoecious species. The same results further emphasise the need to factor in biotic interactions in studies on community descriptors and to employ composite environmental variables rather than single variables in testing for their putative influence on beach macrofaunal assemblages. This study also suggests that extremely short beaches can still sustain stable macrofaunal communities, and, in the absence of human disturbance and extreme stochastic events, these can act as refuges for otherwise rare psammophilic species.

\section{Acknowledgements}

The authors wish to thank the following taxonomists for their contribution in identifying species collected in this study: Dr S. Schembri, Dr P. Gatt, Mr D. Dandria, Prof. E. DeMatthaeis, Prof. A. Vigna Taglianti, Dr G. Nardi, Dr L. Magnano, Dr P. Leo, Dr I. Lobl, Dr V. Assing, Prof. J-M. Thibaud, Prof. V. Mahnert and Prof. J. Martens. We are grateful to the University of Malta for financial support through the award of research grants.

\section{References}

Axiak, V., Gauci, V., Mallia, A., Mallia, E.A., Schembri, P.., Vella, A.J. 1999. State of the environment summary report for Malta 1998. Environment Protection Department, Ministry for the Environment, Floriana, Malta, $130 \mathrm{pp}$.

Brazeiro, A., 1999. Community patterns in sandy beaches of Chile: richness, composition, distribution and abundance of species. Revista Chilena de Historia Natural 72, 93-105.

Brazeiro, A., 2001. Relationship between species richness and morphodynamics in sandy beaches: what are the underlying factors? Marine Ecology Progress Series 224, 35-44.

Brown, J.H., Kodrick-Brown, A., 1977. Turnover rates in insular biogeography: effects of migration on extinction. Ecology 58, 445-449.

Carpaneto, G.M., Fattorini, S., 2001. Spatial and seasonal organization of a darkling beetle (Coleoptera, Tenebrionidae) community inhabiting a Mediterranean coastal dune system. Italian Journal of Zoology 68, 207-214.

Caruso, D., Lombardo, B.M., 1982. Isopodi terrestri delle isole Maltesi. Animalia 9, $5-52$

Clarke, K.R., Warwick, R.M., 1994. Change in Marine Communities: An Approach to Statistical Analysis and Interpretation. Natural Environment Research Council, Plymouth, 144 pp.

Clarke, K.R., Gorley, R.N., 2006. PRIMER v6: User Manual/Tutorial. PRIMER-E Plymouth, $190 \mathrm{pp}$

Colombini, I., Chelazzi, L., 1996. Environmental factors influencing the surface activity of Eurynebria complanata (Coleoptera, Carabidae). Revista Chilena de Historia Natural 69, 511-537.

Colombini, I., Aloia, A., Fallaci, M., Chelazzi, 1996. Spatial and temporal strategies in the surface activity of some sandy beach arthropods living along the French Atlantic coast. Marine Biology 127, 247-257.

Colombini, I., Fallaci, M., Chelazzi, L, 2005. Micro-scale distribution of some arthropods inhabiting a Mediterranean sandy beach in relation to environmental parameters. Acta Oecologica 28, 249-265.

Covazzi Harriague, A., Albertelli, G., 2007. Environmental factors controlling macrofaunal assemblages on six microtidal beaches of the Ligurian Sea (NW Mediterranean). Estuarine, Coastal and Shelf Science 73, 8-16.

Defeo, O., Gomez, J., Lercari, D., 2001. Testing the swash exclusion hypothesis in sandy beach populations: the mole crab Emerita brasiliensis in Uruguay. Marine Ecology Progress Series 212, 159-170.

Defeo, O., McLachlan, A., 2005. Patterns, processes and regulatory mechanisms in sandy beach macrofauna: a multi-scale analysis. Marine Ecology Progress Series $295,1-20$. 
Degraer, S., Volckaert, A., Vincx, M., 2003. Macrobenthic zonation patterns along a morphodynamical continuum of macrotidal, low tide bar/rip and ultradissipative sandy beaches. Estuarine, Coastal and Shelf Science 56, 459-468.

Deidun, A., Schembri, P.J., 2004. Is faunal diversity on Maltese sandy beaches related to intensity of human use? In: Micallef, A., Vassallo, A. (Eds.), Proceedings of the First International Conference on the Management of Costal Recreational Resources - Beaches, Yacht Marinas and Coastal Ecotourism, 20-23 October 2004. Malta. Euro-Mediterranean Centre on Insular Coastal Dynamics, Foundation for International Studies, Valletta, Malta, pp. 23-29.

Deidun, A., Schembri, P.J., (in press). Assessing inter-beach differences in semiterrestrial arthropod assemblages on Maltese pocket sandy beaches (Central Mediterranean). Marine Biology.

Dugan, J.E., Jaramillo, E., Hubbard, D.M., Contreras, H., Duarte, C., 2004. Competitive interactions in macroinfaunal animals of exposed sandy beaches. Oecologia 139, 630-640.

Fallaci, M., Colombini, I., Taiti, S., Chelazzi, L., 1996. Environmental factors influencing the surface activity and zonation of Tylos europaeus (Crustacea: Oniscidae) on a Tyrrhenian sandy beach. Marine Biology 125, 751-763.

Fallaci, M., Colombini, I., Palesse, L., Chelazzi, L., 1997. Spatial and temporal strategies in relation to environmental constraints of four tenebrionids inhabiting a Mediterranean coastal dune system. Journal of Arid Environments 37, 45-64.

Henderson, P.A., Seaby, M.P.H., 2002. Species Diversity and Richness Software 3.03. Pisces Conservation Ltd, Lymington, UK.

Jaramillo, E., Contreras, H., Quijon, P., 1996. Macroinfauna and human disturbance in a sandy beach of south-central Chile. Revista Chilena de Historia Natural 69, 655-663.

McLachlan, A., Jaramillo, E., Donn, T.E., Wessels, F., 1993. Sandy beach macrofauna communities and their control by the physical environment: a geographical comparison. Journal of Coastal Research 15, 27-38.

McLachlan, A., Dorvlo, A., 2005. Global patterns in sandy beach macrobenthic communities. Journal of Coastal Research 21, 674-687.

Micallef, A., 2003. Monitoring beach stability on the Mediterranean island of Malta. In: Ozhan, E. (Ed.), Proceedings of the Sixth International Conference on the Mediterranean Coastal Environment, MEDCOAST 03, 7-11 October 2003, Ravenna Italy. MEDCOAST, Middle East Technical University, Ankara, Turkey, pp. 1357-1368.
Mifsud, D., Scupola, A., 1998. The Tenebrionidae (Coleoptera) of the Maltese Islands (Central Mediterranean). Annali del Museo Civico di Storia Naturale 'G. Doria' 92, 191-221.

Mifsud, D., 1999. Tenebrionids associated with sandy shores in the Maltese Islands (Coleoptera, Tenebrionidae). The Central Mediterranean Naturalist 3, 23-26.

Nardi, G., Mifsud, D., 2003. A review of the Anthicidae of the Maltese Islands (Central Mediterranean). Fragmenta Entomologica 35, 77-127.

Norussis, M.J., 1993. SPSS for Windows: Professional Statistics, Release 6.0. PrenticeHall Publishing, New York, 84 pp.

Nucci, P.R., Turra, A., Morgado, E.H., 2001. Diversity and distribution of crustaceans from 13 sheltered sandy beaches along Sao Sebastiao Channel, south-eastern Brazil. Journal of the Marine Biology Association of the UK 81, 475-484.

Rodil, I.F., Lastra, M., 2004. Environmental factors affecting benthic macrofauna along a gradient of intermediate sandy beaches in northern Spain. Estuarine, Coastal and Shelf Science 61, 37-44.

Rodil, I.F., Lastra, M., Sanchez-Mata, A.G., 2006. Community structure and intertidal zonation of the macroinfauna in intermediate sandy beaches in temperate latitudes: north coast of Spain. Estuarine, Coastal and Shelf Science 67, 1-13.

Scapini, F., Chelazzi, L., Colombini, I., Fallaci, M., 1992. Surface activity, zonation and migrations of Talitrus saltator on a Mediterranean beach. Marine Biology 112, 573-581.

Seaby, M.P.H., Henderson, P.A., 2007. QED Statistics 1.1.3.443. Pisces Conservation Ltd, Lymington, UK

Thomas, M.L.H., 1986. A physically derived exposure index for marine shorelines. Ophelia 25, 1-13

Veloso, V.G., Cardoso, R.S., 2001. Effect of morphodynamics on the spatial and temporal variation of macrofauna on three sandy beaches, Rio de Janeiro State, Brazil. Journal of the Marine Biological Association of the UK 81, 369375.

Walther, B.A., Moore, J.L., 2005. The concepts of bias, precision and accuracy, and their use in testing the performance of species richness estimators, with a literature review of estimator performance. Ecography 208, 815-829.

Weslawski, J.N., Stanek, A., Siewert, A., Beer, N., 2000. The sandhopper (Talitrus saltator, Montagu, 1808) on the Polish Baltic coast: is it a victim of increased tourism? Oceanological Studies 29, 77-87. 